\title{
UNDERSTANDING THE SOCIAL ENVIRONMENT DETERMINANTS OF STUDENT MOVEMENTS: A CONSIDERATION OF STUDENT ACTIVISM IN THAILAND AND THE THAI "SOCIAL CAGE"
}

\author{
Siwach Sripokangkul* \\ Research Group on Local Affairs Administration, \\ College of Local Administration, Khon Kaen University, \\ 123 Friendship Highway, Khon Kaen, 40002, Thailand \\ E-mail: siwasri@kku.ac.th \\ John Draper** \\ Research Group on Local Affairs Administration, \\ College of Local Administration, Khon Kaen University, \\ 123 Friendship Highway, Khon Kaen, 40002, Thailand \\ E-mail: johndr@kku.ac.th \\ Charles David Crumpton***
}

Institute for Governmental Service and Research, University of Maryland, 4321 Hartwick Road, Suite 208, College Park, MD 20742-3225, United States

Email: ccrumpto@umd.edu

Autthapon Muangming ${ }^{* * * *}$

Khamnadee Subdistrict Administrative Organization,

14 Bueng Kan, 38000, Thailand

E-mail: aut.colakku@gmail.com

Published online: 15 January 2019

To cite this article: Sripokangkul, S. et al. 2019. Understanding the social environment determinants of student movements: A consideration of student activism in Thailand and the Thai "social cage." International Journal of Asia Pacific Studies 15 (1): 59-96, https://doi.org/10.21315/ijaps2019.15.1.3

To link to this article: https://doi.org/10.21315/ijaps2019.15.1.3 


\begin{abstract}
Student activists have played notable roles in national social and political movements. Deploying a variety of analytic approaches, extensive research has been conducted regarding student movements in terms of their causes, their operational characteristics, and their relationships with broader intra-and inter-societal social and political forces. Yet the literature concerning the impact of student movements is unclear regarding the organisational and institutional environment determinants of their emergence and durability. Little attention has been directed at considering student activism through the prisms of social movement theory, institutional theory and organisational study. The current study seeks to address this situation through a consideration of student movements in Thailand. It builds upon the recent work of Kanokrat (2016) in her application of social movement theory to student activism in Thailand to consider the implications of what Clemens and Cook (1999) refer to as the "social cage" of institutional interests. This synthesised analytic approach is applied in an assessment of the contemporary Dao Din student movement of Northeast Thailand, arguably Thailand's highest profile student movement since the 2014 military coup.
\end{abstract}

Keywords: Dao Din student activists, institutional theory, social cage, student movements, student movement theory, Thailand

\title{
INTRODUCTION
}

Student movements occupy a prominent place in our memories of social action and political change. Images of students defying army tanks, barricading streets or placing flowers in the barrels of bayoneted rifles easily come to mind. While student movements have been extensively studied from a variety of perspectives, adequate theory and analytic frames to guide our understanding of student movements and their relationships with broader intra- and intersocietal social and political forces have been lacking. The current study aims to address this deficiency.

More specifically, this study looks beyond existing considerations of student movements from a variety of perspectives, including that of social movement theory, to examine what concepts and analytic approaches drawn from institutional analysis and organisational study might be useful to consider student activism. With a focus on evidence concerning the Dao Din student activism in Northeast Thailand, this study utilises and then moves beyond Kanokrat's (2016) social theory driven analysis of Thai student activists of the 1970s. It seeks to offer analytic tools to more fully consider the student activist 
experience in Thailand within the distinct context of the Thai "social cage" that we describe in the subsequent discussion.

Organised student action is at least as old as the European model of the university. Students during the Middle Ages in Bologna, Paris, Oxford and Cambridge organised to act upon their grievances against university administrations, governments and fellow townsmen (Boren 2001). With the global spread of the European university model, students have continued to organise for political and social change (Weiss and Aspinall 2012). A review of modern student movements reveals that they have diverse motivations. Their triggering stimuli have ranged from complaints about university administration policies to demands for governmental regime change. In terms of ideology, student activism has tended to be leftist, but there has also been rightist student action, such as the support for the Italian and German fascist movements of the 1920s and 1930s. While students served as a powerful political force in Europe and North America in the 1960s, they also played pivotal roles in independence movements of the mid-twentieth century in Africa, Asia and Latin America (Gill and DeFronzo 2009).

A substantial body of literature has been dedicated to understanding student movements. They have been examined in terms of their ideological roots, their internal organisation, their leadership characteristics, and social and psychological dimensions associated with their participants (Altbach 1970; Boren 2001; Bevington and Dixon 2005; Boggs 2006; Haberman 2006; Gill and DeFronzo 2009; Rhoads 2016; Weiss and Aspinall 2012). Yet, student movements have not been adequately explained in terms of their organisational and institutional environment determinants. In particular, there has been inadequate theory and analytic frame development concerning the relationship between the student movement organisation as a type of social movement organisation and the organisational and institutional environments in which they emerge and seek to survive. Combining insights from social movement theory, organisation study and institutional theory, we consider organisational and institutional environment factors that both impede and facilitate student movement organisations' ability to find an organisational place and institutional legitimacy in its societal setting to realise institutional change (Minkoff 1997; Clemens and Cook 1999; McAdam and Scott 2005; Armstrong and Bernstein 2008; Zald and Garner 2017; Zald and Useem 2017).

We will rely on six sources of understanding. First, the international/intercontextual body of literature concerning student movements will be reviewed. Second, in that student movements should be considered as a sub-type of social movements, social movement theory will be examined. Third, since we argue 
that, following McAdam and Scott (2005) and others, institutional theory and organisational study improve the analytic capacity of social movement theory, we will turn to these sources of understanding. Fourth, to provide a rich contextual setting for examining the nuances of student movements over time, we will consider 90 years of student movements in Thailand. Fifth, we will assess student activism in Thailand, considering the consequences of Thai institutional arrangements and changes in the Thai economy, particularly the growth of the middle class. Finally, we will focus attention on a slice of Thailand's student movement history, that involves the current Dao Din movement of Northeast Thailand, the most visible student movement in the region since the 1970s. We argue that the recent Dao Din experience both reflects historic institutional factors that have either facilitated or impaired student activism. Additionally, it offers insight into the current dormancy of effective student action against the anti-democratic state of political and social affairs produced by the Thai "social cage."

\section{Methods}

This study should be viewed as primarily theory-building and theory-testing. It does this by synthesising several existing sets of theory and research, utilising this synthetic understanding to build upon existing research on student activism in Thailand, and applying the resultant understanding to examine a particular case of Thai activism. The sets of theory and research that will be considered are student movement theory, social movement theory, institutional theory and organisational study. The existing research is that of Kanokrat (2016), who applied social movement theory to examine the experience of the survivors of violent suppression of student protests in October 1976 by the Thai military regime. We enhance Kanokrat's essentially cognitive/transactional approach by applying institutional and organisational analysis. Finally, we analyse the experience of a regional student protest group, the Dao Din of Isan in Northeast Thailand. In our analysis of information gathered through interviews with individual Dao Din members, examination of contemporary media coverage of the Dao Din, and results of a focus group of Dao Din members, we apply the synthetic understanding gained through blending student movement theory, social movement theory, institutional theory, organisational study and the work of Kanokrat to build an assessment of the Dao Din experience. 


\section{LITERATURE REVIEW}

\section{Student Movements}

To begin our consideration of student movements, we present a useful definition of "student movement." Gill and DeFronzo (2009: 208) offer the following:

... we define a student movement as a relatively organized effort on the part of a large number of students to either bring about or prevent change in any one of the following: policies, institutional personnel, social structure (institutions), or cultural aspects of society involving either institutionalized or non-institutionalized collective actions or both simultaneously.

This definition emphasises institutional/structural contexts and places the causes and effects of social movements in these contexts, thus providing framing assistance for our study. It is consistent with Haberman's (2006) assessment of student movements in the United States, Canada and Mexico. She found that student movements were fruitful to the extent that they were well connected to institutionalised political processes.

Rhoads's (2016) review of over 50 years of student movements in the United States shows that student collective action has been most effective when it has been directly connected to organisational resources accessed through societal institutionalised structures and processes. Rhoads's discussion of the American experience indicates that movements that are marginalised from the mainstream of political institutionalised processes, such as early gay rights activity and the Occupy Wall Street movement, have tended to have only passing relevance. These can be compared to the civil rights and anti-war student movements of the 1960s, which provided critical support for broader societal activity that resulted in substantive policy changes. Minkoff (1997) argues that the civil rights and anti-war movements created organisational conditions that benefited subsequent student-supported social movements in the United States. Further focusing on societal institutional factors associated with student political and social action, Gill and DeFronzo (2009) argue that researchers have tended to offer typologies of student activism rather than student movements and have inadequately focused on the structural and cultural contexts of these movements, on which they might best be seen as dependent. 
In their collection of studies concerning Asian student movements, Weiss and Aspinall (2012) focus on the political implications of student activism. They agree with our assessment that relatively little theoretical or comparative work has been performed to consider determinants of student activism. Drawing upon existing research and the findings of the Asian research offered in their book, Weiss and Aspinall (2012: 8-10) state that four inter-related questions guide their analysis:

First, what is it about university students that gives them such political, and specifically vanguardist, potential? Second, what accounts for varying levels of coordination between students and other actors in civil and political society?... this study aims to view "student" as a problematic collective identity... only productive of student activism under certain circumstances that require explanation... Third, what are the impacts of regime type, prevailing laws, and regime strategies of co-optation and repression on the scope and nature of student activism?... Lastly, what accounts for apparent transnational patterns of student protest cycles across this region?

The current study will offer robust responses to Weiss and Aspinall's second and third questions.

While Weiss and Aspinall (2012) recognise student activism as a form of social movement, they invest little effort in considering social movement theory as a source of explanations. Weiss and Aspinall (2012) inadequately account for social environmental conditions identified by Minkoff (1997), Armstrong and Bernstein (2008), Rhoads (2016) and others that influence the rise of social movements. For movement organisations to arise and survive, they must make effective connections with organisational resources from institutionalised interests. Weiss and Aspinall (2012) also inadequately account for another structural consideration that affects student movements globally: the mass transformation of societies to middle-class status (see Edwards, Evans and Smith 2012).

We enhance Weiss and Aspinall's (2012) analysis of student movements by focusing attention on how social environmental conditions affect the emergence, their influences on, and the survival of, Thai student movements. Using the toolbox of institutional theory and organisational study, we consider how the "social cage" (Clemens and Cook 1999) of Thai institutions and the political consequences of the transformation of Thailand into a middle-class society have affected Thai student movements. 


\section{Social Movement Theory}

Weiss and Aspinall (2012) indicate the literature considering student movements provides an incomplete theoretical framework for student movements. Therefore, we turn to the broader theoretical and empirical literature concerning social movements. In her consideration of Thai student movements of the 1970s, Kanokrat (2016) acknowledges the importance of social movement theory to understanding the subject of her research, the "Octobrists" - a group of survivors of the 6 October 1976 Thammasat University Massacre, an attack by Thai state forces and far-right paramilitaries on student protesters, following student protests against the return of former military dictator Thanom Kittikachorn to Thailand from Singapore. As we use social movement theory, our study might be viewed as a companion piece to Kanokrat's work.

A brief review of key concepts from social movement theory that assist in understanding student movements is useful. Opp (2009: 41) argues that a definition of social movement should be placed in relation to definitions of "protest" and "protest group":

A "social movement" is a certain kind of a "protest group." But what are the special features of a social movement? Two dimensions are frequently mentioned in the literature... one is some degree of formal organisation ... Another feature that is often associated with the term "social movement" is size. Typical social movements such as the peace movement are relatively large groups.

According to Meyer (2015), the emergence and sustenance of social movements involve a calculus that includes urgency for change, goals that address needed changes, and linkages among institutionalised societal stakeholders with similar views regarding the need for change and the needed changes. Social movements influence change by building upon connections with institutionalised interests. Gamson (2015) suggests their success can be measured by the extent they influence patterns of social action and/or find a place among the institutional actors.

As a product of his survey of the dominant theoretical and analytic approaches to understanding social movements, Opp (2009) proposes a synthesis of collective action, resource mobilisation, political opportunity, identity, and framing perspectives into a structural-cognitive model. Although he includes institutional and organisational variables, Opp inadequately considers the institutional and organisational environment that social movements seek to influence. 
Morris (2000) argues social movements should be viewed in terms of relationships with the political structures and processes of the societies in which they are situated. Social movements that have societal impacts find linkages with social and political forces and established institutional arrangements. This is a two-step move. First, social and political conditions that favour social change offer opportunities for social innovators to develop organisational capacity to start "movements." Second, organised social movements ignite social and political action which results in societal change. The extent to which this occurs is dependent on social movement organisations finding allies among institutionalised economic, social and politics interests.

The argument that the relationship between the organisation of social movements and their ultimate impact on social conditions, including policy outcomes, received empirical support in Cress and Snow's (2000) research concerning the United States homeless movement. He showed that when activists have connections with institutionalised social values and policy processes and structures of their policy space, the potential of realising movement objectives as policy outcomes is enhanced. Altbach and Cohen (1990) offer a vivid example of this with student movements. Their study of American university divestment in the international battle against apartheid in South Africa demonstrates the role student activism played in policy change. The political objectives of the student movement aligned with emerging social attitudes of university leadership and national social and political attitudes concerning South Africa.

\section{Kanokrat's use of social movement theory}

In her consideration of Thai student activism of the 1970s, Kanokrat (2016) draws upon social movement theory. As she tells the story of the Octobrists, survivors of the 6 October 1976 Thai military attack against student protesters, she utilises three analytic frames drawn from the work of McAdam, McCarthy, Zald, Tarrow and others. In applying the political opportunity structure frame, Kanokrat considers political environment conditions that facilitate or constrain social action. Opportunities for social change organisations to act are dependent on structural and ideological shifts among those in power (Kanokrat 2016: 18). The appearance of the Octobrists on the Thai political scene and their subsequent political participation over the next four decades were seen by Kanokrat as individual cognitive responses to shifts in the Thai political environment. As she applies resource mobilisation theory in her analysis, Kanokrat considers the material and nonmaterial resources required 
to sustain a social movement organisation. This includes the construction and utilisation of political resources to create political networks for the social movement organisation to effect its political framework. In their pre-1976 and subsequent political activities, the Octobrists realised political success or were thwarted in relation to their ability or inability to marshal political assets. As Kanokrat considers framing process, she is primarily interested in how ideas, beliefs, issues and symbols were framed for purposes of defining collective identity and to mobilise resources in the social environment. She emphasises the importance of alignment or misalignment between frames held by student activists and those in their social environment.

Of interest to our consideration of Thai student activism is Kanokrat's focus on the relationship between the student movement organisation and its political and social environment. We see a limitation in her assessment of the institutional and organisational environment in which the student activists - and ex-activists - operated. Her assessment is primarily transactional and driven by cognitive transformations among individual Octobrists that allowed them to support a range of political orientations over time and changing circumstances. We argue that the experience of the Octobrists was primarily determined by one of the analytic frames utilised by Kanokrat: political opportunity. The 1970s presented a unique set of political opportunities that offer little generalisable value in analysing how the Thai social and political environment has operated over time. Allowing the 1970s situation to frame the analysis fails to account for the enduring characteristics of the Thai institutional environment "social cage" (per Clemens and Cook 1999; see subsequent discussion). Other central structural characteristics of Thailand over the past 40-50 years are not thoroughly considered. In particular, the implications of the rise of the Thai middle class and its political "co-optation" by the nation's established conservative political order is not taken into account. Co-optation in this sense is not to be seen as a simplistic process as it involves various factors that interact to create a socio-politically stable authoritarian state (Baker 2016). The rise and persistence of authoritarian power in Thailand in recent decades has been attributed to the alliance between the institutions of the military and the monarchy, which has been described as traditionally "paternalistic" (in Thai, Paw Khun; Suwannathat-Pian 2013: 24-26). This viewpoint sees branches of the military "as the guardians of the monarchy and of a very patriarchal concept of democracy and ultimately as genuine political actors" (Heiduk 2011: 264), serving the king as a virtual deity, at least under King Rama IX (Jackson 2010), via a networked system of patronage of favourites under semi-monarchical rule. This has been described both as a "network monarchy" 
(McCargo 2006) and as a "parallel state" led by a "monarchised military" (Chambers and Waitoolkiat 2016). Thus, the production of Thai history, for example, is used to socialise Thais according to a Thai royalist-nationalist historiography which tends to co-opt the middle classes (Winichakul 2001). In that the political roles that middle-class Octobrists played in the decades after the 1976 massacre can be considered as evidence of the middle class's political "co-optation" via such socialisation mechanisms, this is an interesting oversight by Kanokrat.

\section{Institutional Theory and Organisational Study}

With the work of Zald and Ash (now Garner) in the 1980s, social movement theory began to consider the internal organisational dynamics of social movement organisations and organisational variables in their social environments (Gamson 2015). As social movement theory moved to consider organisational variables within and beyond social movement entities, organisational study began to examine environmental factors beyond its focus on rational micro-organisational structures and processes (McAdam and Scott 2005). Many students of organisations adopted an organisational ecology perspective that privileges survival in the social environment over efficiency or effectiveness (McAdam and Scott 2005). The importance of organisational ecology was applied to social movements by Minkoff (1997), who argued that social movement organisation survival is dependent on organisational conditions in the political environment (Minkoff 1997). For example, "early riser" civil rights and anti-Southeast Asian War movements created organisational conditions in the social environment of the United States that made it possible for subsequent social movements to arise and survive (Minkoff 1997).

In the 1990s neo-institutional theory was introduced to organisational studies to emphasise the importance of normative and cultural frameworks to the emergence and sustenance of organisations. Organisations were assessed according to their "social fitness": their cultural and normative legitimacy and accountability in their social environments (McAdam and Scott 2005). McAdam and Scott (2005) argued social change processes are mediated by organisational factors in their environments. Organisational fields tend toward stability representing "institutional settlement" among dominant actors and their institutional allies. Social change organisations are successful in introducing change to the extent key actors in the organisational field modify their institutional logic to embrace values and beliefs of the social innovators (McAdam and Scott 2005). 
Analysis of institutional change sought by student activism and other forms of social movements is enhanced by blending institutional theory with organisational studies and social movement theory. Clemens and Cook (1999) emphasise the durability of societal institutional arrangements: key institutions of economic, social and political authority tend to be interlinked to form what they refer to as "social cages" that resist change and social innovators. They acknowledge that the salience of established regimes can be threatened by external or social environmental changes. However, such threats will be mediated by political conditions that existing powers control. The endurance of established regimes is not a product of their existence as a unitary whole, but rather a product of "institutional thickening" of connections among multiple institutional actors to create a resilient "social cage." Armstrong and Bernstein (2008) observe that multiple loci of institutional power challenge the ability of social movements to create coherent narratives that can challenge the established institutional order. The institutional thickening of connections among societal institutions results from shared or complementary norms and common interest in societal stability. This results in a powerful "taken-for-grantedness" of existing institutional arrangements reinforced by control of political access by established authorities (Clemens and Cook 1999). For institutional innovators to realise opportunities for social change, they must make connections with existing institutional interests. As a result, institutional change is never created de novo-it relies on existing institutional resources. This is clearly consistent with Minkoff's (1997) assessment that social movements can only realise social change if they create alliances with established institutional interests. This also aligns with Zald and Garner (2017) who argue that to understand the potential and actual course of social movements, the determining institutional characteristics of the social environment must be understood. Zald and Garner (2017) argue that the legitimacy of social movement organisations will depend on the readiness of potential supporters in their social environments to be mobilised to their causes.

Student movements in Thailand and the experience of Thai student movement organisations must be assessed in terms of these organisational and institutional factors. The implications of the Thai version of the "social cage" and the social fitness of student movement organisations prove to be important considerations. The Thai "social cage" has been largely successful in resisting the social changes sought by student movements and limiting their opportunities to pursue such changes for many decades. 


\section{Thai politics and the emergence of the Thai middle class}

Economic variables are among structural characteristics of social environments that social movements often seek to affect. As a result, a review of Thai economic conditions and the dramatic changes in the Thai economy over the past 50 years should be considered. How economic changes in Thailand might be seen as having an impact on the experience of Thai student activism should also be considered. Before we consider how changing economic conditions in Thailand have affected student activism, it is useful to briefly consider the trajectory of modern Thai politics, to which the economy has had paramount importance.

\section{Thailand's history of political turmoil}

Since Thailand began its transition to a constitutional monarchy, its political environment has been almost continuously unstable. Between 1932 and 2014 there were 13 coups and an equal number of aborted or failed coups (Ferrara 2015). Since the end of the absolute monarchy, Thailand has had 20 constitutions, representing both small and large shifts in the political order. Typically, they involve responses to immediate economic, social and/or political conditions (McCargo 2007).

With the Sarit-led coup of 1958, a pattern of Thai politics was established. Ferrara (2015: 150) describes this as "Thai-style democracy" (prachathippatai baeb thai). In this formulation, stability and security is valued above individual rights and freedoms. "Western" notions of accountability assume secondary importance. The concept involves a "traditional" social order wherein everyone knows his or her place and social change is equated with economic advance. This can be viewed as the establishment of a persistent Thai institutional settlement that produced the "social cage" as described by Clemens and Cook (1999).

From the late 1960s into the 1990s, Thailand experienced a rise of mass political participation, including large demonstrations involving students, leftists, and working-class participants. Yet each surge in political participation was met by a conservative reaction by military-led and monarchy-endorsed coups. The conservative influence of the 1958 Sarit revolution could be discerned in the military coup of September 2006. The often-brutal repression of democratisation was justified by reference to Thai nationalism, stability to promote economic development, and increasing mystification of the King (Ferrara 2015). These intermingled values and symbols contributed to the durability of the Thai "social cage" to resist social change agents. 
Consistent with this five-decade-long pattern, the latest coup in 2014 was stimulated by reaction from conservative forces unwilling to accept electoral setbacks in 2011. The coup sought to "install an uncorrupted form of 'Democracy with the King as Head of State' - a 'democracy' where elections do not matter, dissent is crushed in the name of 'unity,' and everyone loves the King" (Ferrara 2015: 12). The institutionalised social order might introduce new labels, but the pre-existing institutional settlement and institutional logic remained constant.

\section{Political implications of Thailand's emergent middle class}

The literature of international economic development typically identifies Thailand as an economic "success story." Thailand's per capita GDP grew more than ten-fold between 1960 and 2015, from approximately USD 570 to nearly USD 5,800. The World Bank's (2016) description of Thailand as a successful upper-middle class economy reflects this common assessment. The Bank emphasises the average growth rate of 7.5 percent between 1960 and 1996, and five percent between 1999 and 2005 (after the Asian crash), the creation of millions of jobs, and substantial reductions in poverty.

This economic transformation included a dramatic growth of the Thai middle class. Defining and measuring the middle class of any nation is an imperfect exercise and Thailand is not an exception. Englehart (2003) concurs with Ockey's assessment that the "new rich"—urban white-collar workers, professionals and business owners - form the core of the Thai middle class. The Thai middle class grew from 15 percent of the workforce in 1960 to 34 percent in 2000. This growing segment of the Thai population reflects internationally recognisable consumption patterns in terms of housing, transportation and commodities (Facts and Details 2017).

How has the growth of Thailand's middle class affected the institutional characteristics of the Thai social and political environment and prospects for Thai student movements? Modernisation theory posits that growth in national wealth as indicated by development of a large middle class will result in a movement toward democratisation and broader political participation. However, Englehart (2003) and Hewison (2014) have separately argued that this has not been the case in Thailand.

Offering reinforcement for Englehart's (2003) assessment, in his analysis of the politics after the 2014 coup, Hewison (2014) argues that the Thai middle class is not the natural "ballast" of democratisation. It values its social and economic self-interest above specific political characteristics 
of Thai society. He states that the Thai middle class has found comfort in the nationalistic and royalist imagery proffered by non-democratic regimes, especially in the semi-divine nature of the Thai king as a righteous Buddhist god-king (dhammarachaldevaraja) represented in the 20th and 21st centuries in the form of King Rama IX (Sarun 2010), source of "Thainess," and symbol of "absolute theologico-political power" (Jackson 2010: 48, citing Morris 1998: 370). The middle class has been effectively politically co-opted in the sophisticated fashion outlined above by the regime in a way that reflects the interests and values of the Thai "social cage."

The resultant "taken-for-grantedness" of Thai institutionalised regime values allowed for what Sopranzetti (2016: 300) describes as a "relapse into dictatorial administrative structures, political attitudes and military-led class alliances" akin to those of the 1970s. This alignment goes far beyond the ambiguities of a "new" social movement or the reductionist paradigm of an enemy of an enemy being a friend (Sopranzetti 2016: 305, note 17) in that it involves: (1) re-making of a state administration involving strong personal dictatorship, with General Prayuth at one point Chairman of the National Council for Peace and Order (NCPO), Chief of the Army and Prime Minister; (2) new re-mystified ideology embracing ultra-royalism, anti-corruption and moral good governance; and (3) new class alliance involving elites, the military and the middle class (Sopranzetti 2016). Manipulation of powerful Thai symbolism has provided rationale for the middle class's acceptance of anti-democratic coups (Englehart 2003; Hewison 2014; Chachavalpongpun 2017).

Modernisation theorists typically posit that, with economic growth and increased societal wealth, there is an expansion of civil society. This phenomenon can be discerned in Thailand during the period of its economic expansion (Hewison 2014). However, while modernisation theory also indicates that growth of civil society will support movement toward democratisation, Hewison (2014) argues that this has not occurred in Thailand. Rather, civil society has generally reflected the middle-class acquiescence to institutionalised power.

The preceding review of the role of the middle class and civil society in Thai politics since the 1970s should condition Kanokrat's (2016) analysis of the political history of the Octobrists. As she describes the experiences of 1970s middle class university student activists after the violent incident of 6 October 1976, she inadequately accounts for a transformational change in the social environment of Thailand: the economic boom, the creation of a mass middle class, and the sophisticated political co-optation of the middle 
class into the established Thai "social cage." If we combine institutional and organisational analysis with that of Englehart (2003), Hewison (2014) and Chachavalpongpun (2017), we see that, while the emergence of a large middle class and a co-occurring expansion of civil society has changed the Thai social milieu, the durable power of the Thai "social cage" must be taken into account to consider Kanokrat's (2016) three-part analytic framework.

\section{Student Movements in Thailand}

Thai student activism dates back at least 90 years. Though high-school students were involved in protests of the 1970s (Ungpakorn 2006: 571), this article focuses upon university or vocational college-based students. While they have not been active in recent decades, there have been exceptions. A notable exception is the Education for the Liberation of Siam, a small group of mainly elite, anti-military students active since the 2014 coup.

In February 1927, seven Thais, five of whom were students, met in Paris to plot a revolution against the Siamese monarchy. Calling themselves the Khana Ratsadon, or People's Party, and led by a law student, Pridi Banomyong, they adopted the aims of converting the absolute monarchy into a constitutional monarchy and achieve six outcomes: "true independence, public safety, economic planning, equal rights (with no exceptions for royalty), liberty for all, and universal education" (Phongpaichit and Baker 2015: 115). These themes remained central to Thai student activism and broader democratisation movements over the next nine decades.

During the 1940s and 1950s, Thai student activism was sporadic, with occasional notable moments. It was seen in the Indochinese border protest against France in 1940. It took dramatic form during the Second World War: approximately 100 Thai students trained with Allied forces during 19411942 and in 1943, some were dropped in and killed behind enemy lines (Ferrara 2015). In December 1952, under the second Field Marshal Plaek Pibulsonggram administration, 200 leftist politicians, students, thinkers and writers were arrested in the Peace Rebellion (Kabot Santiphap) for plotting to overthrow the government (Ferrara 2015). Students played a limited role in Pibulsonggram's Hyde Park free speech and democracy experiment of 1955 in Bangkok. The February 1957 election in which the Socialist Front won two parliamentary seats allowed student activists to openly voice their anti-government/pro-democracy opinions. As the Phibun regime foundered, students and Hyde Park supporters combined to offer support to Field Marshall Sarit Thanarat against Phibulsonggram and Police Chief Phao Siyanon. 
Marching to Government House to demand that Phibun resign, they helped to trigger the Sarit coup of September 1957 (Ockey 2002; Ferrara 2015).

Kongkirati (2012) describes the 1960s and 1970s, a time of intense student activism around the world, as the zenith of student activism in Thailand. The emergence of large-scale Thai student activism in the 1960s was in part due to an important institutional shift in Thailand involving a new emphasis on national development. The emphasis included the creation of new public regional universities: Chiang Mai (1964), Khon Kaen (1966) and Prince of Songkla (1967) Universities. These complimented the existing elite Central Thai universities: Chulalongkorn (1917), Thammasat (1934), Mahidol (1943) and Kasetsart (1943). Beginning as agricultural and technical colleges, the regional universities provided places for, and at the same time helped define, the regions' aspiring middle classes. The development of the Rajabhat provincial college system throughout the 20th century and the 1971 founding of Ramkhamhaeng University, an open university with approximately 525,000 students at present, also provided thousands of new places for the children of the middle classes, and especially in the 1990s as intake expanded, the lower middle classes, throughout Thailand. These universities also provided avenues for lower-middle and middle-class students from the regions to contribute to the public sphere, joining the traditionally upper-middle class students of the Bangkok universities. Historically, subject fields have been stratified by class, with medical fields generally being pursued by upper class Sino-Thai students. Students of "lower" social classes populate the humanities and engineering, then agricultural fields, etc. Consequently, university student population grew from 18,000 in 1961 to 100,000 in 1972. Also, a growing number of middleclass Thai students (mainly studying art at first) were studying abroad. As the student population grew, so did student dissatisfaction with the military's control of public universities (Baker and Phongpaichit 2014). This rising dissatisfaction was tied to global events, including the wave of student revolts in the 1960s, culminating with the 1968 student movements of North America and Europe. It was propelled by libertarian left-wing ideas, which penetrated Thailand via popular and scholarly articles, books, music, and other media sources. The success of the communist parties in Indochina following the defeat of the United States in Vietnam also energised the Thai Seventies (Ungpakorn 2006: 571).

This study argues that the Thai student activism can be subjected to the institutional and organisational analysis introduced above. A shift in the social environment to value students as a national development resource and student access to new organisational sources on university campuses presented 
opportunities to challenge the existing Thai "social cage" and opened the way to the high point of student activism in the 1970s.

Student dissatisfaction in the 1960s reflected a variety of perspectives. It was both reformist and traditionally nationalist. It reflected opposition to the crass materialism of the United States and was a blend of socialism and Buddhism. This could be seen in the new journal Sangkhomsat Parithat (Social Science Review), founded in 1963. Within a few years, this and similar journals were feeding students activists with ideologically New Left articles that targeted poverty, exploitation of peasants and urban labourers, and social justice (Baker and Phongpaichit 2014: 184-185). Student activism found some support from King Rama IX himself, who urged students to combat corruption, although he also felt "students must be controlled" and that open student demonstrations were "very wrong" (Baker and Phongpaichit 2014: 185, citing Suwannathat-Pian 2013: 161). Again, using institutional analysis to examine this period of student activism in Thailand, we see encouragement of student activism through linkages to important institutionalised interests in the Thai social environment and access to political space.

Student demonstrations protesting corruption, the Southeast Asian war, and other sources of discontent began to build slowly in 1968 and reached full flow by 1972. The Communist Party of Thailand (CPT) saw the revolutionary potential of this growing student discontent and recruited student leaders, though the leftist ideas of the students were intermingled with democratic liberalism, Buddhist concepts of social justice, and nationalistic opposition to exploitation by Japan and the United States. As noted above, many student activists were from rural areas and the first in their lower- to lower-middleclass families to attend university (Baker and Phongpaichit 2014). According to an institutional analysis, although student activism was in part animated by values that threatened the institutionalised Thai social order, it was also consistent with deeply held Thai religious and nationalistic values.

In November 1972, the student activists struck, with Thirayuth Boonmi leading students from the National Student Centre of Thailand (NSCT) on a 10-day protest against Japanese products. In June of the following year student demonstrations focused on restoring a democratic constitutional regime. However, the conservative government retaliated. After arresting student leaders, the military junta discussed eliminating two percent of the university student population, with the objective of purging what they viewed as student revolutionaries. This action was in part rationalised as a response to what they saw as manipulation of the students by communists (Baker and Phongpaichit 2014). 
Yet, the student activists found support beyond university campuses, especially after 13 student leaders were arrested on 6-9 October 1973, for leafleting popular gathering points in Bangkok calling for a new constitution. The press took up their cause. A mass protest of half a million people, including a broad representation of Thais, took place on 13 October 1973 in Bangkok, calling for an unconditional release of the prisoners (Prizzia 1985: 59-71). Additional protests took place in provincial urban areas. The generals conceded some ground by releasing the student leaders. Seeking the protection of the king, demonstrators moved to the palace to avoid military harassment. Student leaders extracted a concession from the generals to produce a new constitution within a year and were granted a royal audience. However, as the crowds dispersed on 14 October, they were fired upon by the military, resulting in 77 dead and 857 wounded, including many students. This shredded the junta's legitimacy, resulting in three generals, Thanom, Praphat and Narong, going into exile. These events promoted the political roles of the students and presented an image of their interests conjoined with those of the monarchy (Baker and Phongpaichit 2014: 186). The student activists were engaged in a dangerous dance among institutional interests that pitted the legitimacy of the junta against that of the students.

Realising political opportunity and connections to societal resources (Kanokrat 2016), the students' role in politics continued in the 1970s. This involved a complex interplay with both radical movements and more moderate institutionally mainstream interests seeking a post-military society. Students campaigned on hot-button issues, such as closing United States bases, but also embraced broader issues of social and economic justice. Thammasat University became the site of public debates which, increasingly influenced by the CPT, slowly shifted leftward. In fact, by mid-1976, most universities and colleges possessed influential Left (mainly Maoist CPT-influenced) student bodies, including Kasetsart University, previously seen as a bastion of the right. These student bodies successfully temporarily suppressed the strictly hierarchical Thai university seniority system and inter-university football matches in favour of summer camps with villagers. Making linkages with other interests in their social environment, the students coordinated with labourers concerning their disputes, participating in hundreds of strikes in 1972-1974. This labour action culminated in students organising a new labour body in mid-1974. These organised efforts pressured the government to make concessions in arbitrating strikes, raising the minimum wage, and legalising the unions. In May 1975, building on developments in peasant awareness that included formation of the Peasants Federation of Thailand in November 
1974, students, workers and peasants established an alliance to fight for peasant issues (Baker and Phongpaichit 2014; Ungpakorn 2006). Thus, the mid-1970s was a period during which student activism found linkages in its social environment, successfully co-produced outcomes valued by allies, and challenged the legitimacy of dominant actors in the Thai "social cage."

By early 1976, a rise of rightist ideologies challenged the progress made by the students with their new allies in civil society. Students found themselves under attack by an influential anti-communist judge, Thanin Kraivixien. Thanin viewed the students as part of the "inseparable trio of communism, student activism and progressive politics" (Morell and Samudavanija 1981: 236). The scene was being set for a disaster for student activism. Praphat attempted but failed to return to Thailand in August 1976, with two student protestors killed in rightist attacks. Thanom succeeded in returning, as a monk, on 19 September and was visited by the king and queen. On 25 September, two workers protesting Thanom's return were lynched. A rightist newspaper, Dao Siam, suggested that a student re-enactment of the lynching was an attack on the prince (Mallet 1978: 90). Consequently, army-controlled radio stations accused the student protesters of lèse-majesté (see Streckfuss 2010) raised the spectre of the students being communist agitators, mobilising anti-communist counter-insurgent movements to "kill the communists" (Handley 2006: 235). On 6 October 1976, rightist forces, including the paramilitary Village Scouts, Red Gaur and Nawaphon fired heavy weaponry into Thammasat University (Anderson 1977: 19-20; Ungphakorn 1977: 10-11). In the immediate aftermath, the military's general staff overthrew civilian Prime Minister Seni Pramoj (Mallet 1978: 91) and, under the name of the "National Administrative Reform Council," announced it had seized power to prevent a Vietnamesebacked communist plot and to preserve the Thai monarchy. The King appointed the anti-communist and royalist judge Thanin Kraivichien to lead a loyalist government (Mallet 1978: 91). The Thammasat University Massacre effectively ended student protests until the 1990s and set the tone for brutal repression through the balance of the 1970s and into the 1980s (Morell and Samudavanija 1981). The military acting unrestrainedly against anti-royalist Thais produced enduring fear for many of those involved in the events, in that, due to a culture of impunity supported by the ruling elite, none of the perpetrators were brought to justice (Culture of Impunity 2016). It is useful to analyse this turn against student activism with arguments offered by Zald and Useem (2017). The reaction against the students can be seen as a countermovement (although with little popular support) that was benefited by support from the institutionalised status quo. Since established authorities controlled 
political access, including access to public spaces, they could privilege counter movements with organising resources and disadvantage social change movements (Zald and Useem 2017). This is apt analysis for the diminution of Thai student influence from the mid-1970s until the 1990s.

Following the February 1991 military coup, the Student Federation of Thailand joined the Campaign for Popular Democracy, formed from 40-50 NGOs and affiliated student and professional interest groups, to demand democratic reform. Support swelled for this new coalition as the military-appointed Constitution Scrutinizing Committee dominated proceedings and the pro-military party, Samakkhi Tham, emerged in an alliance with some of those the coup had ousted. The high point of this resistance was five days of protests in May of 1991 (Connors 2001). Since the zenith of their 1970s activities, student activists have coalesced with prodemocracy, environmental, non-governmental organisations and grassroots groups in protests, but they have not played lead roles. Antimilitary protests in May 1992, demonstrations against the Thaksin government in 2006 and 2008, and antiAbhisit government activities in 2009 and 2010, as well as, most recently, anticoup activists exemplify this. While university students have been involved in these anti-government demonstrations, they were not leaders who could command mass movements (Kongkirati 2012). Their organisational identity and ability to link with institutionalised organisational interests continued to be too weak to support opportunities to promote social change and challenge the Thai "social cage."

\section{Consolidating evidence from the literature}

In the preceding discussion, we found analytic power in social movement theory. We also found that Kanokrat (2016) usefully applied an analytic framework constructed from social movement theory to consider resource mobilisation, political opportunity and framing perspectives. Bridging and blending social movement theory, institutional theory and organisational study, we have demonstrated how student activism in Thailand should be assessed in terms of the Thai institutional framework and the intricacies of the Thai social environment. We argue that the Thai "social cage" dominated by the military has proven to be a powerful and enduring barrier to student activists.

Kanokrat's analytic framework should be revised to account for considerations we have offered above. We suggest her model can be enhanced to account for the impact of Thai economic conditions and the Thai "social cage" on the trajectory of student activism. We suggest the growth of the 
Thai middle class and its sophisticated co-optation by the established Thai institutional order impacted the resource mobilisation, political opportunity and framing perspectives deployed by Kanokrat in her examination of Thai student activism.

Consideration of the economic transformation of Thailand and the durability of the Thai "social cage" might be utilised to assess Thai student activism on two levels of analysis. First, following Weiss and Aspinall (2012), we suggest that on an individual cognitive level, future economic consequences enter the student's calculus in decisions to participate in student movements. As Weiss and Aspinall (2012: 21) state, “...when students become very fearful that their activism might compromise their future material well-being (job prospects, ability to repay education loans, family welfare, etc.), they may focus cautiously on their role identity, minimizing distractions from their studies." Thus, the absence of students in post-1970s political and social action leadership roles might be partially explained as a product of changing individual student calculus concerning their future prospects, and those of their families, in the emerging middle-class economics of Thailand. Second, on an institutional/organisational level of analysis, we argue that the emergence and survival of student movement organisations will be dependent on the institutional and organisational characteristics of the social environment that they seek to change.

Englehart (2003) and Hewison (2014) say post-1970s Thailand democratisation movements found limited support from the Thai middle class and civil society. Thailand's middle class generally acquiesced to and at times supported anti-democratic coups. This was because of their interest in maintaining societal stability needed to support economic development objectives. They were effectively co-opted by the Thai "social cage" of institutionalised interests dominated by the military. Therefore, it is reasonable to argue that the three analytic dimensions utilised by Kanokrat will be enhanced by including these institutional and organisational concepts.

Mobilisation of students, their connections with supportive societal resources and the framing of political, economic and social issues were influenced by the growth of the Thai middle class and the institutionalisation of ideation consistent with economic development objectives comingled with imagery associated with the Thai monarchy. In the following consideration of the history of the Dao Din student activists of Northeast Thailand we will utilise these analytic insights. 


\section{THE DAO DIN STUDENT ACTIVISTS OF THAILAND}

An example of student activism in Thailand after the Thammasat University Massacre of October 1976 is the Dao Din student group that emerged in 2009 in Thailand's northeast region, or Isan. This chapter of Thai student activism arose in response to natural resource exploitation and environmental law abuse. Isan is a mineral-rich region of Thailand. Gold, iron ore and rock salt have attracted the interest of international investors. Ignoring Thai laws designed to guard against environment depredation and public health harms resulting from natural resource exploitation, the national government has failed to adequately enforce requirements for environmental and health impact assessments in Northeast Thailand. This failure of the national government to protect the environment and public health has resulted in severe health impacts in communities adjacent to mining sites (Ford 2014). The failure of the national government to protect the interests of the villages of northeast Thailand has been exacerbated by the historic dominance of local governance by the national government (Unger and Mahakanjana 2016).

In several Northeast Thailand districts, communities affected by mining operations have organised to oppose these abuses. This nascent resistance movement was met by violence, including assassination of protest leaders (Subcommittee for Studying and Investigation a Case of Gold Mining Problem, National Human Rights Commission of Thailand 2004; Thaipublica 2014). In response to the violent repression of community protests, a group of law students who refer to themselves as Dao Din (Stars on Earth) joined the opposition to the mining exploitation and governmental negligence. Comprised of students in the new law faculty at Khon Kaen University (KKU), the Dao Din brought their ideology and legal knowledge to provide substantive support to assist in fighting the perceived social injustice experienced by the villagers of Isan. The Dao Din students literally linked arm-in-arm with the residents of communities affected by the mining abuses and shared in physical intimidation experienced by the local protestors.

The rise of the Dao Din student activists occurred at the time of the establishment of the Faculty of Law at KKU, the first in Northeast Thailand, in 2009. Their interest in the plight of Northeast Thai villagers who were facing economic and physical abuse at the hands of capitalists and the government was partially stimulated by field study that was part of their university studies. As they visited the villages of Isan, the law students returned to the classroom questioning why Thai law was not utilised to protect the interests of the villagers. One of the Dao Din founders, Kornchanok Saenprasert (Chim 2013) 
observed, "[1] earning in the classroom is not enough, so we want to learn from villagers. This shows that the real problem in society is injustice at all levels done to villagers. Therefore, we gathered in a group to study various problems of injustice and their origins." This in essence reflects Thailand's People's Movement of the first half of the 2000s, with its creed that "The answer lies in the village." In this vein, the Dao Din are also basically Autonomists, following a form of Localist Anarchism (chumchon-niyom) that emphasises self-organisation at the community level and ignores the state in the hope that it will become irrelevant (Ungpakorn 2006: 583, citing, for example, Holloway 2002).

As noted by another Dao Din participant, Jatupat Boonpattararaksa (Mongkolsuk 2013), the freedom that the law students experienced in their studies to learn about the real-life problems of rural Thailand contributed to empowering them to be effective activists:

As students, we have a lot of freedom, which gives us pure power. If we spend four years just studying and after graduation, we look for a job for ourselves, we live very self-centred. We however, think that during these four years we have the opportunity to learn more than others. We should repay society by helping others and learn the truth about what happens in our society.

Examples of the Dao Din activists collaborating with villagers to oppose the exploitation of their region include protesting against potash mines in Udon Thani and construction of a cassava flour factory in Nam Pong district of Khon Kaen province, conducting a study of the problems associated with the construction of a power plant in Kalasin province, and seeking to strengthen the legal protection of the community surrounding gold mining in Loei province (Matichon Weekly 2014). The Dao Din also expressed interest in broader issues of social equity such as labour rights for provincial villagers.

In addition to the freedom that the Dao Din students experienced in their law studies, their opportunities to engage with villagers to oppose capitalist and governmental exploitation were enhanced by the recent emergence of village activism in Isan. Phatharathananunth (2016) has written that after the 2006 military coup, villagers in Isan participated in anti-coup and pro-democratic activities. This newly-found opportunity to express political voice is seen by Phatharathananunth (2016) as a product of socio-economic forces noted above. In that Isan is home of the largest rural population in any of Thailand's regions, this emergent rural activism might be seen as a notable challenge to the institutionalised order in the Thai political environment. 
The Dao Din have found support for their general ideological position beyond emergent villager activism, within and outside of Northeast Thailand. Civil society groups allied with the Dao Din to oppose the 2014 coup and push for social justice include Thai Lawyers for Human Rights, the Internet Law Reform Dialogue, the Single Gateway Opposition, the Commoners' Party of Thailand, the New Northeasterners' Movement and the Organisation of Free Thais for Human Rights and Democracy.

During the period of 2013-2014 Thailand experienced political crisis due to political conflict and violent clashes involving protesters of the People's Democratic Reform Committee (PDRC) who sought to overthrow the government led by Prime Minister Yingluck Shinawatra, the sister of Former Prime Minister Thaksin Shinawatra. The protesters were eventually successful in ousting the government in May 2014. This was the product of an anti-democratic movement that demanded the military bring about an end to political conflict. Although some students joined the PDRC political movement, other students joined opposing groups and organised activities to demand that all parties search for peaceful resolution through the democratic process. These activities included peaceful demonstrations and university discussion forums. The Dao Din group was one of the student groups that was active in this democratic reconciliation movement (Haberkorn 2015).

The re-emergence of student activism should be viewed in the context of the anti-democratic military coup of 2014 that installed a military dominated government. As Haberkorn (2015) states:

...[T]he May 2014 coup ushered in a regime that has made the constriction of political freedom one of its signature tactics. During the first year following the coup, all protest was swiftly quashed. Arbitrary arrest and detention, torture, and political prosecutions have taken place on a scale not seen since the anti-communist dictatorship that followed the October 6, 1976 massacre and coup... Military courts have been instituted for civilians for the first time since the late 1970 s... Sentences range from three years for anti-monarchy graffiti to fifty years in prison for critical Facebook posts. Disseminating leaflets with anti-coup messages is enough to be charged with sedition...

In 2015, in defiance of the military junta's orders against public demonstrations, Dao Din students in Khon Kaen joined students in Bangkok as part of the New Democracy Movement (NDM) in peaceful protests on the one-year anniversary of the May 2014 coup. Fourteen students were arrested by the police, including seven of the Dao Din group. The student demonstrations and 
the arrests stimulated broader protests by fellow students, faculty members, and members of the general public (Haberkorn 2015).

In their relationship with the NDM, the Dao Din became part of an informal national network of student activists. Through their participation in the NDM, the Dao Din aligned with other university-based groups, including the Liberal League of Thammasat University for Democracy, the Chulalongkorn Community for the People (CCP), the Liberal Group of Kasetsart University, the Group of Villagers' Successors at Burapha University, Seri Nonsi at Kasetsart University and the Liberal Assembly of Chiang Mai University for Democracy, as well as with Resistant Citizen, a pro-democracy activist group, and the Assembly for the Protection of Democracy.

The posture of the Dao Din student activists in resisting the military regime is reflected in the assessment of one of its members:

The movement opposing the military takeover comes from our feeling that the coup impacts communities and that villagers are affected by the development plans. These problems are interlinked. We cannot just move ahead in leaps. There are explanations that because of the military coup d'état, rights of villagers are violated too. The Dao Din group therefore thinks that this is an important factor and a reason for us to protest the coup. In the past, we could express ourselves; although they would not listen, villagers could gather to protest and voice their opinions. But after the NCPO stepped in and took over, activities by villagers articulating their views are all blocked and prohibited and locals are threatened. The situation was bad but has now worsened (Saraprang, personal communication, 30 June 2016).

The students who identified themselves as Dao Din in 2014-2015 on the national stage of opposition to the military regime were still animated by the injustices that they had seen among the villages of Isan since 2009.

In our focus group of current Dao Din members, we heard this continuing commitment to local issues. Yet we also heard their commitment to broad changes to Thai society. The Dao Din were asked whether they primarily saw themselves as engaged in a class struggle, in a struggle of the periphery against the centre, or in an ethnic conflict involving the Thai Lao against the Central Thai. They said they were involved in all three, as they were interrelated. They were primarily involved in a struggle of the centre versus the periphery because of the power imbalance, then secondarily in a class struggle, and thirdly in an ethnic conflict. The issue of a power imbalance connected all three. If they could fight to reduce the power of central government, other people in the 
other groups (lower classes, ethnic minority communities) would have more power. The Dao Din see their main opponents as the capitalists who cause the problems the villagers face and those who blindly support the military. In the terminology of institutions and organisations, the Dao Din sought to disrupt the Thai institutional settlement and institutional logic that had defined the political and social environment since the 1950s.

The Dao Din are willing to ally themselves with anyone trying to confront the regime. As Autonomists, they see villagers as their natural allies. They see themselves as representing village-level local issues and support a role for the public sector in providing education. They also see as natural allies the Neo-Isan Movement. Further, the Dao Din have progressed ideologically beyond Autonomism in that they now support a small, radical national political party, the Commoners' Party of Thailand, which incorporates elements of "direct democracy" self-organised local community action (see Ungpakorn 2006: 584-585). In both the Neo-Isan Movement and the Commoners' Party of Thailand, Dao Din alumni are active members or leaders. However, while they have "thick" relationships with other marginal groups dedicated to economic, environmental, political and social justice issues, they can claim no connections with institutionalised members of Thailand's "social cage" or interests that might seriously challenge the social settlement that has defined it for decades. Although the Dao Din generally self-identify as members of the Thai lower-middle to middle-middle class, since the middle class has been effectively co-opted by the institutionalised arrangement of authority, they find few allies in their economic class.

Although the Dao Din group is Thailand's highest impact student movement in terms of protests, arrests and media exposure, it has effectively been contained by the military regime. Active civil society disobedience has been restricted to "scattered student groups, provincial Red Shirt supporters and outspoken academics" (Elinoff 2014). Civil society has largely been coopted by the current regime. The Thai middle class has demonstrated that it values its economic wellbeing more than it does social and political change. While "ongoing confrontations [on the regional level] over issues like gold mines, evictions from forests, housing problems and infrastructure projects have re-mobilized previously existing activist networks" (Elinoff 2014: 379), the Dao Din and their allies, such as the Neo-Isan and New Democracy Movements, are denied access to funding and networking opportunities by the established regime. Although the Dao Din have attracted sympathy from village protestors as representing their single-issue movements in the face of 
martial law (Lee and Darin 2014), this group has many of the weaknesses of autonomist movements in that it has not reproduced itself or emerged as an institutional actor. Nor has it been able to reproduce itself as representing the interests of the common man or of villagers in general, only the most radical kind. The Dao Din have been successful in generating numerous media stories in the alternative media, mainly Prachatai. Yet, they have received limited attention from mainstream media.

The marginal status of the Dao Din in the Thai social environment is also discerned through consideration of its ethnic characteristics. The Dao Din is essentially a group from the Thai Lao Northeast that reflects Thai Lao sensibilities. On the national scene Thai Lao aspirations have been long misunderstood and ignored. If the Thai Lao protested, they were labelled as communists, ignorant peasants or dehumanised as stupid "buffaloes," blindly following former Prime Minister Thaksin Shinawatra, instead of supporters of democracy (Keyes 2014). In this context, the Dao Din protests follow a long line of violently suppressed Thai Lao revolts in what Keyes (2014: 190), quoting Phongpaichit and Baker (2015: 227), describes as "the dispossessed against an old political establishment."

The military regime has successfully restricted the capacity of the Dao Din and other student activists in Thailand to organise and act. Since they are part of public universities under the control of the central government, they are particularly vulnerable. This restriction on the organisational capacity of the Dao Din has also impeded their ability to effectively pursue their original mission - to assist the villages of the Isan in opposing economic and governmental exploitation (Lucksanawong 2016). The repression is particularly harsh and involves psychological warfare against the students and their social networks, including the intimidation or recruitment of family members (Lee and Darin 2014), as well as criminal charges and detention without bail against the group's informal leader, Jatuphat Boonpattararaksa (Prachatai 2017b) and charges of contempt of court against members of Dao Din (Prachatai 2017a). For Dao Din activists, repression has caused a form of cognitive dissonance such that "they are trapped inside a perimeter that is slowly closing in around them, while the rest of society quietly pretends not to see it" (Sopranzetti 2017: 233). Students of institutional change argue that it is dependent on access by social change entrepreneurs to potential allies in the institutional order. The Thai military regime has been generally successful in assuring that this access is not available the Dao Din and other student activists. 
Beyond the military regime's restriction on the activism of the Dao Din, the inability of the group to impact social, political and economic outcomes in Thailand has been related to broad societal changes in Thailand over the past 40 years, as discussed above. The national political passivity that provided the political space for the military coup became the national norm among the beneficiaries of Thai economic growth. Thus, after the military coup of 2014, the Dao Din and other university activists had fewer allies in Thai society with whom they could connect in order to demand social, political and economic change (Chachavalpongpun 2017).

\section{Analysis: The Dao Din experience and a revision to Kanokrat}

Although the evidence concerning the experience of the Dao Din student activists covers a relatively short period time, it is sufficient to allow us to apply analytic perspectives discussed earlier. We will consider the Dao Din experience in terms of concepts that represent a blend of student movement theory, social movement theory, institutional theory and organisational studies, and the work of Kanokrat (2016).

\section{Applying the Kanokrat analytic framework}

The 1970s represented a unique opportunity in the history of Thai student activism for student groups to participate in the nation's political discourse. Applying the political opportunity analytic frame used by Kanokrat (2016), we find that this unique political opportunity offered an opening for the Octobrists to not only become part of the national political conversation, but to continue to be political actors into the future, albeit in much less radical roles. Applying the political opportunity frame as described by Kanokrat to the Dao Din we see a much different situation. While the Dao Din were successful in finding political opportunities to link with regional village level interests in shared opposition to the abuses of Thai capitalism, and on the national level with groups opposed to the 2014 anti-democratic coup, more generally their political opportunities have been severely limited. As we discussed earlier, the economic and political environment of Thailand changed dramatically during the 40 years following the massacre of 6 October 1976. Thailand had been transformed into a middle-class society. The burgeoning middle class had been politically co-opted by the conservative political elite dominated by the military. As demonstrated most recently in the 2014 coup, the "social cage" of Thai institutions had reasserted its authority to limit democratic access to political space necessary for social change agents to emerge and survive. 
In her consideration of student activists, Kanokrat (2016) considers the conditionality of resource mobilisation in protest activism. That is, different resources will be mobilised in different ways in response to different contextual conditions. Social change organisations need networking opportunities to mobilise resources that they need to actively pursue their social change agendas. In response to repressive regime conditions, the Dao Din have utilised their formal place in the law faculty of KKU to create a variety of informal linkages on the regional and national levels to pursue their interests in societal change. Some linkages exhibit indications of formalisation/institutionalisation. The formation of the NDM might be assessed according to these terms, though the NDM is largely dormant at present. The Dao Din in fact are a loose collective with no formal structure or status, thus inhibiting formal development (Ashayagachat 2014). Government intimidation and active repression have prevented the Dao Din from building organisational capacity to sustain their activities. The Dao Din have not possessed the networking needed to mobilise resources to promote its objectives related to societal change.

Kanokrat (2016) also considers the importance of ideological frames to support movement development. She demonstrated the importance of ideas, issues and symbols in the emergence of student activists in the 1970s and the political activities of the Octobrists in subsequent decades. As reflected in the words of Dao Din participants, these student activists framed their interests and activities in different terms on the regional and national levels. Dao Din translates as "Stars on Earth" (Ashayagachat 2014), reflecting a student activist interest in the affairs of peasants and the desire to be stars that bring light to impoverished people who work the earth (see Winichakul 2001 for the soil/ earth metaphor), to create a more beautiful and equal society. The use of the term "Dao Din" therefore appeals to the peasantry in terms of offering assistance, rekindling the attempted alliance in the 1970s between the student movement and the peasantry. Military repression and intimidation of Dao Din students, were framed in an October 2014 petition by 200 academics and students calling for Thai universities to preserve wisdom and promote academic freedom of expression, citing the potential failure of KKU to guarantee the integrity of its student registration system (Prachatai 2014). The Dao Din have attempted to frame symbols of democracy to protest against the junta. The Dao Din students have unsuccessfully attempted to reproduce themselves by framing their interests as those of the "common man" in their declarations. Support from other student groups has been largely formalistic and ineffective. On the national level, the Dao Din have emphasised combatting inequality, a severe problem in Thailand (Credit Suisse 2016). The battle has been embodied in the 
Dao Din adopting the three-fingered salute of the Hunger Games movies as their symbol of protest. While the Dao Din have created framing that has been useful in formulating their self-identity, it has had limited value in building external support needed to promote its objectives involving national social and political change in Thailand.

Just as Kanokrat (2016) finds value in applying the political opportunity, resource mobilisation and framing approaches to consider the experience of the Octobrists, they assist in assessing the Dao Din. Yet, as we argue regarding Kanokrit's study, we assert that the Dao Din experience must be assessed in terms of additional institutional and organisational considerations. In particular, the durable power of the Thai "social cage" is an immense deterrent to student activists such as the Dao Din.

\section{Applying institutional theory and organisational study}

Clemens and Cook (1999) discuss how thick linkages form among established societal institutions to form a "social cage" dedicated to maintaining stability and resisting change in the social environment. Minkoff (1997), and McAdam and Scott (2005), among others make institutional theory and organisational study-based arguments that social movements are able to arise, stimulate social change and survive in their social environments to the extent that they successfully create effective linkages to institutionalised interests, thus creating openings in the "social cage." In a cognitive/transactional manner Kanokrat recognises this in the of rise student activists in the 1970s. However, we assess that she inadequately considered the durable power of the Thai "social cage." In analysing the experience of the Dao Din, while we acknowledge the value of Kanokrat's three-part analytic approach, we argue additional institutional and organisational concepts must be considered to understand the fate of the Northeast Thailand student activists. The organisational capacity of the Dao Din and their ability to influence social change in Thailand has been constricted by the resilience of the Thai "social cage," particularly as it has been exhibited by the military regime's restriction of student activist access to the Thai political space. Without opportunities to link with influential established institutional interests in the Thai social and political environment, the limited impact of the Dao Din is predictable.

Thailand has lacked "early riser" social movement organisations as described in the work of Minkoff (1997) to help pave the way for the Dao Din and other groups. This is probably because Thailand of 2017 is not the United States of the 1960s wherein civil rights and anti-war activists could 
build organisational resources available to subsequent social movements. The "social cage" of Thailand does not allow the political access or space for this to happen.

\section{Impact of Thai economic variables}

The scholarship of Englehart (2003), Boudreau (2004), Hewison (2014) and Chachavalpongpun (2017) support an assessment that Thai economic development as seen in the growth of the Thai middle class has had important impacts on democratisation and on the careers of the Dao Din. We see different faces of this impact on the regional and national levels. On the regional level, economic development has offered opportunities for villagers to find political voice (Keyes 2014). It has also provided mobilisation resources for the growth of Isan civil society. This has positively impacted the political opportunities, resource mobilisation and framing opportunities for the Dao Din in the pursuit of their justice interests in their Northeast Thai home. However, consistent with the analysis of Englehart (2003), Hewison (2014) and Chachavalpongpun (2017), we also see that on the national level the Thai middle class and civil society have tacitly, and at times actively, supported the anti-democratic regime (see also Baker 2016) to contribute to a stifling of the Dao Din and their pro-democracy allies and limit their ability to challenge the Thai "social cage."

\section{DISCUSSION AND CONCLUSION}

Using the current example of the experience of the Dao Din of northeast Thailand, we have found that scholars of student movements, social movement theory, institutional theory and organisational study have much to offer in describing and analysing student activism. We have argued that the addition of concepts drawn from institutional theory and organisational study, and consideration of the transformation of Thailand into a middle-class society enhances the analytic approach of Kanokrat (2016) to add analytic power to understand the emergence, impact and survival of student activism. Something that can be discerned in our analysis is the importance of the social environment-both on the national and subnational levels. As indicated in the work of Boudreau (2004), we also find that nation-specific contextual factors will impact the way that economic transformation will impact democratisation. The role of Thai royal imagery and the linkages among institutional interests to promote economic development objectives likely has produced different outcomes than 
Boudreau (2004) observed elsewhere in Southeast Asia. The characteristics and impacts of the Thai "social cage" can be expected to be different than those found elsewhere in Asia or on other continents. In the case of the Dao Din we also find that economic variables may work in different ways on the national and subnational levels to impact the prospects of democratisation and student activists. In our consideration of student activism in Thailand, we see how nation-specific conditions impact the applicability of models constructed in other settings. Thus, we found that Minkoff's (1997) useful assessment of the organisational requisites for the rise of social movements based her study of social movements in the United States in the 1960s and 1970s must be adapted to the reality of the Thai "social cage" and the political consequences of the emergence of the Thai middle class.

As economic, social and political changes continue in Thailand, the descriptive and analytic tools that we have introduced here will contribute to understanding these changes and the role and impact of student activists in them. Focusing on the Dao Din of Isan, the approach introduced in this study should help interested analysts in assessing this student group's future place in the economic, social and political evolution of their home region and Thailand as a whole. It will be of continuing interest to students of Thai society and politics to see if and how the "social cage" changes to allow opportunities for the Dao Din and other social movement organisations to find political voice and contribute to social change.

\section{NOTES}

* Siwach Sripokangkul is an assistant professor at the College of Local Administration (COLA) at Khon Kaen University, in Northeast Thailand. He has been the Director of the Research Group on Local Affairs Administration at COLA. His research interests are in violence, reconciliation, civil-military relations and social justice issues. $\mathrm{He}$ obtained his B.A. (first class honors) and M.A. from the Faculty of Political Science at Chiang Mai University, Thailand, and his PhD in Political Science from Thammasat University, Bangkok. His most recent publications are: Sripokangkul, S. (2015), Reconciliation as free-floating signification: Reconciliation after 2014 coup in Thailand, Asia-Pacific Social Science Review 15 (2): 108-132; Sripokangkul, S. (2017), On the path to democracy in Thailand: Military reform is the first step, Asia-Pacific Social Science Review 17 (1): 1-24; and Sripokangkul, S. (2017), The commodification of death: Working of the genocide museum and the killing fields in the reconciliation process in Cambodia, Kasetsart Journal of Social Sciences 38 (2): 537-548. His latest book, On Reconciliation (2017), is available from Khon Kaen University Printing. He can be contacted at siwasri@kku.ac.th. 
** John Draper is Director of the Social Survey Center at the College of Local Administration (COLA) in Khon Kaen, Northeast Thailand, where he is at present working on the Human Achievement in Thailand by Ethnicity Project and teaches an undergraduate course on multicultural management in local administration as well as a PhD course on academic writing. He has a B.A. in Modern History from the University of Oxford and an M.A. in Applied Linguistics from the University of Southern Queensland. His M.A. thesis topic was A sociolinguistic study of a Lao (Isan) community of Northeast Thailand: Implications for language maintenance and language planning. He is presently studying a D.P.A. in Public Administration at COLA, with his dissertation topic being The framing and development of questions and policies regarding Thailand and the "Thai Lao." He has written of over a dozen peer-reviewed international journal articles on topics ranging from language policy to TEFL to the human rights of the Thai Lao, most recently Draper, J. and Kamnuansilpa, P. (2018), The Thai Lao question: The reappearance of Thailand's ethnic Lao community and related policy questions, Asian Ethnicity 19 (1): 81-105. He is author of the Thailand chapter for the Routledge handbook on language education policy in Asia.He can be contacted at johndr@kku.ac.th.

*** Charles David Crumpton received his Master of Public Administration degree from the University of Georgia and his PhD in Public Administration and Public Policy from Portland State University. Dr. Crumpton has experienced a varied public administration and public policy career, including 20 years as a senior public manager at the local and state levels in the United States. Over the past twenty years he has worked as a policy and program analysis consultant, researcher and professor in the United States, Brazil and Thailand. Dr. Crumpton's research has included adult and juvenile justice, child health and welfare, school attendance problems, electronic innovation in justice systems and evaluation of substance abuse, mental health interventions in justice systems, comparative public administration, comparative public policy, comparative social policy, comparative local governance and social policy implementation. He currently serves as a Senior Research Associate with the University of Maryland, College Park's Institute for Governmental Service and Research (IGSR) and teaches in the University of Maryland's School of Social Work. Based in Brasília, Brazil, he assisted the Federal University of Goiás (UFG) in the development of the Center for Public Sector Studies and Applied Research (CEPASP), where he continues to work as a senior researcher. He is also a visiting professor in the College of Local Administration at Khon Kaen University in Thailand. As a Fulbright Specialist in public administration, Dr. Crumpton has received grants to work with Thai and Brazilian universities. He can be contacted at ccrumpto@umd.edu.

Autthapon Muangming works at a Local Administrative Organization in Bueng Kan Province, Northeast Thailand, where he is an independent scholar who has published several articles. He graduated with both his B.A. and M.A. from the College of Local Administration (COLA), Khon Kaen University, in Northeast Thailand. His M.A. dissertation was on civil-military relations before and after the 2014 coup in Thailand. He was also an assistant for the Research Group on Local Affairs Administration at COLA from 2016 to 2017. He can be contacted at aut.colakku@gmail.com. 


\section{REFERENCES}

Activists demanding Pai Dao Din's release accused of contempt of court. 2017a. Prachatai, 17 March. https://prachatai.com/english/node/7010 (accessed 7 May 2018).

Altbach, P. G. 1970. Student movements in historical perspective: The Asian case. Youth and Society 1 (3): 333-357, https://doi.org/10.1177/0044118X7000100305.

Altbach, P. G. and Cohen, R. 1990. American student activism: The post-60s transformation. Journal of Higher Education 61 (1): 32-49, https://doi.org/10.1080/00221546.199 0.11775090 .

Anderson, B. (1977). Withdrawal symptoms: Social and cultural aspects of the October 6 coup. Bulletin of Concerned Asian Scholars 9 (3): 13-30, https://doi.org/10.1080/1 4672715.1977 .10406423$.

Armstrong, E. A. and Bernstein, M. 2008. Culture, power, and institutions: A multiinstitutional politics approach to social movements. Sociological Theory 26 (1): 74-99, https://doi.org/10.1111/j.1467-9558.2008.00319.x.

Ashayagachat, A. 2014. Fingers on the political pulse. Bangkok Post, 21 December. http://www.bangkokpost.com/print/451152/ (accessed 7 May 2018).

Baker, C. 2016. The 2014 Thai coup and some roots of authoritarianism. Journal of Contemporary Asia 46 (3): 388-404, https://doi.org/10.1080/00472336.2016.115 0500 .

Baker, C. and Phongpaichit, P. 2014. A history of Thailand, 3rd ed. Cambridge, UK: Cambridge University Press.

Bevington, D. and Dixon, C. 2005. Movement-relevant theory: Rethinking social movement scholarship and activism. Social Movement Studies 4 (3): 185-208, https://doi. org/10.1080/14742830500329838.

Boggs, A. 2006. A matrix for the comparative study of student movements: Twentieth century Latin American, U.S. and Indian student movements. Higher Education Perspectives 2 (2): 605-669, http://jps.library.utoronto.ca/index.php/hep/article/ view/605/669.

Boren, M. E. 2001. Student resistance. New York: Routledge.

Boudreau, V. 2004. Resisting dictatorship. Cambridge, UK: Cambridge University Press.

Chachavalpongpun, P. 2017. Why is the Thai middle class not fond of democracy? The Japan Times, 9 January.

Chambers, P. and Waitoolkiat, N. 2016. The resilience of monarchised military in Thailand. Journal of Contemporary Asia 46 (3): 425-444, https://doi.org/10.1080/ 00472336.2016.1161060.

Chim, T. 2013. The role of Dao Din student group in movement for environmental protection by ThaiPBS [Video file]. Thai PBS, 12 September. https://youtu.be/gxQU18Pcv-I (accessed 7 May 2018).

Clemens, E. S. and Cook, J. M. 1999. Politics and institutionalism: Explaining durability and change. Annual Review of Sociology 25 (1): 441-466, https://doi.org/10.1146/ annurev.soc.25.1.441.

Connors, M. K. 2001. Ideological aspects of democratisation in Thailand: Mainstreaming localism. Southeast Asia Research Centre Working Papers Series No. 12. Hong Kong: City University of Hong Kong. 
Credit Suisse. 2016. Global wealth data book 2016. Zurich: Credit Suisse Research Institute. Cress, D. M. and Snow, D. A. 2000. The outcomes of homeless mobilization: The influence of organisation, disruption, political mediation, and framing. American Journal of Sociology 105 (4): 1063-1104, https://doi.org/10.1086/210399.

Culture of Impunity. 2016. Prachatai, 3 October. https://prachatai.com/english/node/6612 (accessed 7 May 2018).

Dao Din. 2016. Dao Din declaration on the arrest of Jatupat Boonpattararaksa. Prachatai, 3 December, 2016. https://prachatai.com/english/node/6757 (accessed 7 May 2018).

Edwards, J., Evans, G. and Smith, K. 2012. Introduction: The middle class-ification of Britain. Focaal 2012 (62): 3-16, https://doi.org/10.3167/fcl.2012.620101.

Elinoff, E. 2014. Unmaking civil society: Activist schisms and autonomous politics in Thailand. Contemporary Southeast Asia 36 (3): 356-385.

Englehart, N. A. 2003. Democracy and the Thai middle class: Globalization, modernization, and constitutional change. Asia Survey 43 (2): 253-279, https://doi.org/10.1525/ as.2003.43.2.253.

Facts and Details. 2017. Rich, middle class and poor in Thailand. http://factsanddetails. com/southeast-asia/Thailand/sub5 8c/entry-3229.html (accessed 7 May 2018).

Ferrara, F. 2015. The political development of modern Thailand. Cambridge, UK: Cambridge University Press.

Ford, H. 2014. Digging for gold: Striking resistance. Southeast Asia Globe, 7 April.

Gamson, W. A. 2015. Defining movement "success." In The social movements reader, ed. Goodwin, J. and Jasper, J. M., 382-385. Malden, MA: Blackwell.

Gill, J. and DeFronzo, J. 2009. A comparative framework for the analysis of international student movements. Social Movement Studies 8 (3): 203-224, https://doi.org/ 10.1080/14742830903024309.

Haberkorn, T. 2015. A budding democracy movement in Thailand. Dissent, 30 July. https://www.dissentmagazine.org/blog/new-democracy-movement-thailand (accessed 7 May 2018).

Haberman, C. L. 2006. Centralisation and status formation: Institutional frameworks that shape student movement outcomes. Political Science Honors Projects. Paper 1. http://digitalcommons.macalester.edu/poli_honors/1 (accessed 7 May 2018).

Handley, P. M. 2006. The King never smiles: A biography of Thailand's Bhumibol Adulyadej. New Haven, CT: Yale University Press.

Heiduk, F. 2011. From guardians to democrats? Attempts to explain change and continuity in the civil-military relations of post-authoritarian Indonesia, Thailand and the Philippines. Pacific Review 24 (2): 249-271, https://doi.org/10.1080/09512748.2 011.560959 .

Hewison, K. 2014. Thailand: The lessons of protest. Asian Studies 50 (1): 1-25, http://www.asj.upd.edu.ph/mediabox/archive/ASJ-50-1-2014/01-ThailandLessons-Protest-Hewison.pdf.

Holloway, J. 2002. Change the world without taking power. London: Pluto Press.

Jackson, P. 2010. Virtual divinity: A 21st century discourse of Thai royal influence. In Saying the unsayable: Monarchy and democracy in Thailand, eds. Ivasson, S. and Isager, L., 29-60. Copenhagen: Nordic Institute of Asian Studies.

Kanokrat, L. 2016. The rise of the Octobrists: Power and conflict among former left wing student activists in contemporary Thai politics. Chiang Mai: Silkworm Books. 
Keyes, C. F. 2014. Finding their voice: Northeastern villagers and the Thai state. Chiang Mai: Silk Worm Books.

Kongkirati, P. 2012. Thailand: The cultural politics of student resistance. In Student activism in Asia: Between protest and powerlessness, eds. Aspinall, E. and Weiss, M. L., 229-258. Minneapolis, MN: University of Minnesota Press.

Lee, A. and Darin, C. 2014. Martial law in Thailand's northeast creates common cause between pro-democracy, community rights groups. Prachatai, 20 December. https://prachatai.com/english/node/4624 (accessed 7 May 2018).

Lucksanawong, J. 2016. Thai student activists face more complex issues than just the coup. The Nation, 30 May.

Mallet, M. 1978. Causes and consequences of the October 76 coup. Journal of Contemporary Asia 8 (1): 80-103, https://doi.org/10.1080/00472337885390051.

McAdam, D. and Scott, W. R. 2005. Organisations and movements. In Social movements and organisation theory, eds. Davis, G. F. et al., 4-40. New York: Cambridge University Press.

McCargo, D. 2006. Thaksin and the resurgence of violence in the Thai South. Critical Asian Studies 38 (1): 39-71, https://doi.org/10.1080/14672710600556429. 2007. Introduction: Understanding political reform in Thailand. In Reforming Thai politics, ed. McCargo, D., 1-20. Copenhagen: NIAS Press.

Meyer, D. S. 2015. How social movements matter. In The social movements reader, eds. Goodwin, J. and Jasper, J. M., 386-390. Malden, MA: Blackwell Publishing Ltd.

Minkoff, D. C. 1997. The sequencing of social movements. American Sociological Review 62 (5): 779-799, https://doi.org/10.2307/2657360.

Mongkolsuk, N. 2013. KonAward5 VTR Model Youth Award [Video file] [In Thai]. https://youtu.be/0pEJgCcQw2g (accessed 7 May 2018).

Morell, D. and Samudavanija, C. 1981. Political conflict in Thailand: Reform, reaction, revolution. Cambridge, MA: Oelgeschlager, Gunn \& Hain.

Morris, A. 2000. Reflections on social movement theory: Criticisms and proposals. Contemporary Sociology 29 (3): 445-454, https://doi.org/10.2307/2653931.

Morris, R. C. 1998. Surviving pleasure at the periphery: Chiang Mai and the photographies of political trauma in Thailand, 1976-1992. Public Culture 10 (2): 341-370, https://doi.org/10.1215/08992363-10-2-341.

Ockey, J. 2002. Civil society and street politics in historical perspective. In Reforming Thai politics, ed. McCargo, D., 107-124. Singapore: NIAS Press.

Opp, K-D. 2009. Theories of political protest and social movements: A multidisciplinary introduction, critique, and synthesis. New York: Routledge.

Over 200 Academics, students urge university presidents to protect academic freedom. 2014. Prachatai, 10 December. https://prachatai.com/english/node/4581 (accessed 7 May 2018).

'Pai Dao Din' denied bail again. 2017b. Prachatai, 14 March. https://prachatai.com/ english/node/6998 (accessed 7 May 2018). 
Phatharathananunth, S. 2016. Rural transformations and democracy in Northeast Thailand. Journal of Contemporary Asia 46 (3): 504-519, https://doi.org/10.1080/00472336 .2016 .1166258 .

Phongpaichit, P. and Baker, C. 2012. Revolt of the downtrodden or conflict among elites? In May 2010: Perspectives on a divided Thailand, eds. Montesano, M., Chachavalpongpun, P. and Chongvilaivan, A., 214-229. Singapore: Institute of Southeast Asian Studies.

Phongpaichit, P. and Baker, C. 2015. Introduction: Inequality and oligarchy, In Unequal Thailand, eds. Phongpaichit, P. and Baker, C., 1-31. Singapore: NUS Press.

Prizzia, R. 1985. Thailand in transition: The role of oppositional forces. Honolulu: University of Hawaii Press.

Rhoads, R. A. 2016. Student activism, diversity, and the struggle for a just society. Journal of Diversity in Higher Education 9 (3): 189-202, https://doi.org/10.1037/ dhe0000039.

Sopranzetti, C. 2016. Thailand's relapse: The implications of the May 2014 coup. The Journal of Asian Studies 75 (2): 299-316, https://doi.org/10.1017/s0021911s816000462. 2017. The tightening authoritarian grip on Thailand. Current History 116 (791): $230-234$.

Subcommittee for Studying and Investigation a Case of Gold Mining Problem, National Human Rights Commission of Thailand. (2004). Empirical study for academic data base: A case study of problems in mining for policy suggestions [in Thai]. Bangkok: Subcommittee for Studying and Investigation a Case of Gold Mining Problem, National Human Rights Commission of Thailand.

Streckfuss, D. 2010. The intricacies of lese-majesty. In Saying the unsayable: Monarchy and democracy in Thailand, eds. Ivasson, S. and Isager, L., 105-144. Copenhagen: Nordic Institute of Asian Studies.

Suwannathat-Pian, K. 2013. Kings, country and constitutions: Thailand's political development 1932-2000. London: Routledge.

Thaipublica. 2014. The Mine in Loei province invaded "Wang Saphung" a second time and attacked villagers to pass through the copper mine [In Thai]. 18 May. https://thaipublica.org/2014/05/phu-thap-fah-hit-cyanide-8/ (accessed 30 November 2016).

The road of Dao Din group students' movement [in Thai]. 2014. Matichon Weekly, 24 November. http://www.matichon.co.th/news_detail.php?newsid=1416823130 (accessed 7 May 2018).

Unger, D. and Mahakanjana, C. 2016. Decentralization in Thailand. Journal of Southeast Asian Economies 33 (2): 172-187, https://bookshop.iseas.edu.sg/publication/2170.

Ungpakorn, G. J. 2006. The impact of the Thai 'Sixties' on the peoples movement today. Inter-Asia Cultural Studies 7 (4): 570-588, https://doi.org/10.1080/1464937 0600982925.

Ungphakorn, P. 1977. Violence and the military coup in Thailand. Bulletin of Concerned Asian Scholars 9 (3): 4-12, https://doi.org/10.1080/14672715.1977.10406422.

Weiss, M. L. and Aspinall, E. (eds.). 2012. Student activism in Asia: Between protest and powerlessness. Minneapolis, MN: University of Minnesota Press. 
Winichakul, T. 2001. Prawatisat Thai baep rachachatniyom [Royalist-Nationalist history]. Silapawathanatham 23 (1): 56-65.

World Bank. 2016. Thai overview. http://www.worldbank.org/en/country/thailand/ overview (accessed 7 May 2018).

Zald, M. N. and Garner, R. A. 2017. Social movement organisations: Growth, decay, and change. In Social movements in an organisational society, eds. Zald, M. N. and McCarthy, J. D., 121-141. New York: Routledge.

Zald, M. N. and Useem, B. 2017. Movement and countermovement interaction: Mobilization, tactics, and state involvement. In Social movements in an organisational society, eds. Zald, M. N. and McCarthy, J. D., 247-272. New York: Routledge. 